Kumawula, Vol. 3, No.3, Desember 2020, Hal 492 - 499 DOI: https://doi.org/10.24198/kumawula.v3i3.29697

ISSN 2620-844X (online)

Tersedia online di http://jurnal.unpad.ac.id/kumawula/index

\title{
PENERAPAN KEARIFAN LOKAL DALAM MENINGKATKAN KEMANDIRIAN HIDUP DAN PENGETAHUAN MATEMATIKA DI MASYARAKAT ASLI PAPUA
}

\author{
Etriana Meirista $^{1^{*}}$, Andri Prasetia ${ }^{2}$ \\ ${ }^{1}$ Jurusan Pendidikan Matematika, Fakultas Keguruan dan Ilmu Pendidikan, Universitas Musamus \\ ${ }^{2}$ Jurusan Agroteknologi, Fakultas Pertanian, Universitas Musamus
}

Korespondensi : etriana@unmus.ac.id

\begin{abstract}
Education is very important in human life. Someone who has a good education, cannot be fooled easily. However, economic conditions and community paradigms are inversely proportional to the educational needs that should be met. Some parents in Tambat village in Merauke district prefer their children to help fishing or help to mow the sago instead of having to go to school from morning to afternoon. As a result, school-age children are often seen outside of school during school hours so that the knowledge that should be obtained is not obtained properly. The majority of people's daily activities are farming and hunting. However, for several types of vegetables and herbs, people prefer to buy them because they do not know the procedure and how to plant them. This service is carried out to improve and develop the understanding of mathematics knowledge of school-age children based on Papuan local wisdom which is carried out in the village hall. Initially, children are given number operations, similarity and congruent as well as Cartesian coordinates based on local wisdom based on the learning books that have been made. The children are also invited to go around to learn similarities and congruence and the coordinate system. In addition, this activity also aims to increase community independence by holding training in growing vegetables and herbs in 15 local community yards. The results obtained in this activity are that schoolage children have been able to understand and solve problems in number operations, similarity and congruent, and the coordinate system. Tambat village people can plant and care for their plants properly and use them in their everyday life.
\end{abstract}

Keywords: local culture; independent life; mathematical knowledge; devotion

\begin{abstract}
ABSTRAK
Pendidikan sangatlah penting dalam kehidupan manusia. Seseorang yang mempunyai pendidikan bagus, tidak dapat dibodohi dengan mudah. Namun kondisi perekonomian dan paradigma masyarakat berbanding terbalik dengan kebutuhan pendidikan yang seharusnya terpenuhi. Beberapa orang tua di kampung Tambat kabupaten Merauke lebih memilih anaknya membantu mencari ikan atau membantu memangkur sagu daripada harus pergi ke sekolah dari pagi sampai siang. Hal ini berakibat, anak usia sekolah sering terlihat berada di luar sekolah pada saat jam sekolah sehingga ilmu yang seharusnya diperoleh tidak didapatkan dengan baik. Mayoritas kegiatan masyarakat sehari-hari adalah bertani dan berburu. Namun untuk beberapa jenis sayuran dan bumbu dapur, masyarakat lebih memilih untuk membeli karena tidak mengetahui prosedur dan cara penanamannya. Pengabdian ini dilakukan untuk meningkatkan dan mengembangkan pemahaman pengetahuan matematika anak usia sekolah berbasis kearifan lokal Papua yang dilakukan di balai kampung. Awalnya anak diberikan materi operasi bilangan, kesebangunan dan kekongruenan serta koordinat kartesius yang berbasis kearifan lokal berdasarkan buku pembelajaran yang telah dibuat. Anak pun diajak berkeliling untuk mempelajari kesebangunan dan kekongruenan serta sistem koordinat. Selain itu, kegiatan ini juga bertujuan untuk meningkatkan kemandirian masyarakat dengan mengadakan pelatihan menanam sayur dan bumbu dapur di 15 halaman rumah masyarakat setempat. Hasil yang diperoleh dalam kegiatan ini yaitu anak usia sekolah telah dapat memahami dan menyelesaikan permasalahan dalam operasi bilangan, kesebangunan dan kekongruenan serta sistem koordinat. Masyarakat kampung tambat pun dapat menanam dan merawat tanamannya dengan baik serta mempergunakannya dalam kehidupan sehai-hari.
\end{abstract}

Kata kunci: kearifan lokal; kemandirian hidup; pengetahuan matematika; pengabdian. 


\section{PENDAHULUAN}

Tantangan pada generasi milenial 4.0 lebih menekankan pada penguasaan teknologi dengan tidak menghilangkan karakteristik manusia Indonesia sebagai jati diri bangsa. Pembelajaran bermakna dapat dilakukan dengan menekankan pada prinsip berpikir dan berwawasan global dengan tindakan yang berdasarkan kearifan lokal (Kusuma, 2018). Perkembangan yang ada saat ini, memaksa kita untuk mampu menguasainya dengan cepat. Hal ini mengakibatkan terjadi banyak perubahan secara drastis terutama dalam kehidupan masyarakat setiap hari sehingga makin lama kearifan lokal akan menghilang. Kearifan lokal ini penting untuk dilestarikan karena merupakan ciri khas suatu daerah. Sejak tahun 2006, pemerintah pusat telah mengupayakan banyak cara untuk mempertahankan kearifan lokal sebagai bagian dari warisan yang harus dipertahankan. Salah satu cara melestarikannya yaitu dengan Peraturan Menteri Nomor 22 Tahun 2006 tentang Standar Isi menyatakan bahwa kearifan lokal merupakan bagian dari pengembangan diri yang merupakan bagian dari kompetensi daerah dan keunggulan daerah (Ufie, 2016).

Kearifan lokal dapat dilestarikan dengan menerapkannya pada sebuah kegiatan. Dunia secara umum tidak akan lepas dari era globalisasi dimana kemajuan teknologi yang pesat mengakibatkan setiap orang mampu bersaing dalam penggunaan teknologi. Era globalisasi ini menjadi dasar dalam perubahan masyarakat, dan menjadi tugas semua kalangan masyarakat maupun pemerintah untuk tidak meninggalkan kearifan lokal yang merupakan warisan dari leluhur (Toharudin \& Kurniawan, 2019). Mereka mengganggap bahwa dengan kegiatan mereka sehari hari mampu memberi kehidupan bagi keluarganya tanpa harus bersekolah. Masyarakat hidup masih mempertahankan kearifan lokal yang merupakan warisan turun temurun (Wagiran, 2011).

Kearifan lokal merupakan pikiran tentang hidup. Pemikiran yang dilandasi nalar jernih, budi yang baik dan memuat hal positif. Kearifan lokal diartikan sebagai karya akal budi, perasaan mendalam, tabiat, bentuk perangai dan anjuran untuk kemuliaan manusia. Kearifan lokal (Kusuma, 2018) memiliki ciri identitas suatu daerah, 1) sebagai pemersatu masyarakat, 2) sebagai warisan budaya yang diterima dan dipublikasikan, 3) sebagai kekayaan budaya suatu komunitas, 4) sebagai pola kepentingan umum, 5) sebagai perekat kebersamaan dalam menjaga kelestarian, identitas dari ancaman dan pengaruh dari luar (Basuki, Jufrida, \& Suryanti, 2019). Kearifan lokal merupakan pengalaman panjang yang diendapkan sebagai petunjuk perilaku seseorang dan tidak lepas dari lingkungan penggunanya. Kearifan lokal itu bersifat dinamis, lentur, terbuka dan senantiasa disesuaikan dengan jamannya. Konsep demikian juga sekaligus memberikan gambaran bahwa kearifan lokal muncul sebagai tameng yang melanda kehidupan manusia. Kearifan lokal merupakan proses dan produk budaya manusia serta dimanfaatkan untuk mempertahankan hidup.

Indonesia merupakan negara kepulauan yang dianugerahi keanekaragaman budaya, suku, juga bahasa dari setiap daerahnya (Narulita et al., 2019). Indonesia memiliki kearifan lokal yang berbeda tiap daerah. Di Timur Indonesia, terdapat sebuah kampung Tambat yang terletak di Distrik Tanah Miring Kabupaten Merauke Provinsi Papua. Kampung Tambat memiliki berbagai macam kearifan lokal mulai dari sistem berburu, penentuan batas wilayah adat, dan sistem pendidikan. Kearifan lokal dapat dihubungkan dengan pendidikan di sekolah melalui penerapannya di setiap mata pelajaran di sekolah. Model pembelajaran berbasis kearifan lokal dihubungkan dengan nilai-nilai pelestarian lingkungan dan kehidupan sosial masyarakat untuk mengembangkan sikap peduli menjaga keseimbangan lingkungan (Arman, Asuni, \& Inekso, 2013). Kearifan lokal mampu membangun keseimbangan pada guru dan siswa. Kearifan lokal mengandung nilai luhur nenek moyang yang dapat dijadikan modal 
untuk membangun bangsa dengan karakter yang baik dan kuat (Asriyani \& Hastuti, 2019).

Kearifan lokal dikembangkan untuk meningkatan pendidikan karakter siswa. Kearifan lokal dari setiap daerah memiliki nilai budayanya. Suku Marind merupakan salah satu suku yang ada di Merauke khususnya kampung Tambat. Masyarakat Marind menerapkan pendidikan di keluarganya saat mereka masih kecil dan dilakukan oleh orang tua (Basuki et al., 2019). Pendidikan nilai yang berhubungan dengan perilaku baik terhadap orangtua, alam dan masyarakat. Pendidikan bagi masyarakat marind adalah menjadi manusia sejati yang berwibawa, kekar, kuat, sigap, bermoral dan bermatabat (Arman et al., 2013). Tapi pada kenyataannya, masih banyak masyarakat suku Marind di kampung Tambat yang belum mampu berhitung. Hal ini dikarenakan kurangnya kesadaran masyarakat akan pentingnya pendidikan. Masyarakat lebih memilih anaknya membantu berburu atau bertani dari pada harus ke sekolah. Sehingga banyak anak-anak yang sering bolos sekolah bahkan yang putus sekolah.

Kampung Tambat terletak di Distrik Tanah Miring Kabupaten Merauke. Kampung Tambat memiliki luas 23.855.194 km². Dengan luas daerah yang terbesar di Distrik Tanah Miring, maka bertani merupakan penghasilan utama dari daerah tersebut. hasil pertanian yang utama adalah sagu dan pisang. Dalam bidang pendidikan, kampung Tambat pada tahun 2017 memiliki sekolah dasar (SD) sebanyak 6 kelas dengan banyak siswa 70 orang dan jumlah guru adalah 6 orang. Maka banyak perbandingan antara jumlah guru dan siswa sebanyak 2:35. Artinya bahwa setiap 2 guru menangani 35 siswa (BPS, 2018).

Dari hasil wawancara yang dilakukan, dengan kesibukan dari masyarakat untuk bertani akhirnya mereka menganggap bahwa sekolah tidak penting. Ada anggapan pada masyarakat bahwa dengan tidak bersekolah, seseorang dapat bertahan hidup hanya dengan bertani. Anggapan itu sangat bertentangan dengan kehidupan di era globalisasi saat ini.
Kehidupan saat ini mengharuskan setiap orang harus sekolah atau minimal harus mampu baca, tulis dan hitung. Dari data tersebut, dapat dilihat bahwa perilaku masyarakat di kampung Tambat sangat kuat dengan kearifan lokal yang masih dipertahankan sampai sekarang. Dengan demikian, diharapkan sekolah-sekolah yang berada di sekitar kampung Tambat diharapkan dapat memiliki cara tersendiri dalam mengajar dan menghubungkan kearifan lokal dengan setiap pelajaran. Berhitung merupakan dasar bagi anak untuk dapat memulai pendidikan. Bila anak dapat berhitung, anak tersebut dapat mengaplikasikannya dalam kehidupan seharihari. Berhitung juga merupakan dasar dalam pendidikan karena setiap hari kita akan selalu berhubungan dengan matematika, baik melalui sekolah ataupun di luar sekolah. Penanaman konsep matematika yang paling dasar pada anak adalah operasi hitung, konsep dasar operasi hitung adalah konsep penjumlahan, pengurangan, perkalian dan pembagian (Kurtanto, 2013). Dengan menguasai banyak konsep dalam operasi hitung, akan membantu siswa dalam memecahkan masalah lebih baik. Menghadapi permasalahan tersebut, maka perlu dikembangkan suatu alat peraga yang berhubungan dengan kearifan lokal sehingga dapat melestarikan budaya. Dengan menggunakan kearifan lokal, dapat meningkatkan minat anak untuk belajar.

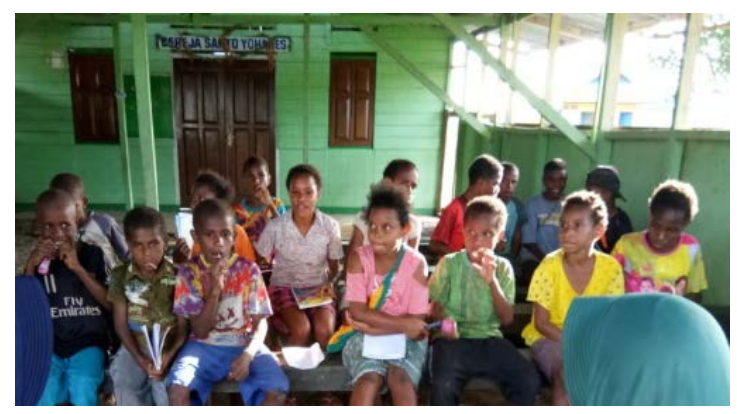

\section{Gambar 1. Wawancara dan observasi awal anak-anak di Kampung Tambat}

Selain berhitung, pengabdian ini akan difokuskan pada cara menanam tanaman sayuran dan bumbu masak di halaman rumah 
masyarakat dengan baik. Bukan hanya cara penanamannya saja yang akan diberikan pada pengabdian ini, namun penentuan tanaman sayuran dan bumbu dapur apa saja yang dapat tumbuh subur di lingkungan masyarakat. Luas wilayah yang ada pada kampung Tambat dan halaman yang cukup luas di perumahan masyarakat tidak dimanfaatkan dengan sebaik mungkin. Halaman rumah masyarakat lebih gersang, bilapun ada hanya tanaman hias yang berada disana.

Berdasarkan analisis situasi yang ada, maka pengabdian ini dilakukan untuk meningkatkan pengetahuan matematika dengan menerapkan kearifan lokal kampung Tambat dan meningkatkan kemandirian hidup masyarakat kampung Tambat

\section{METODE}

Kegiatan pengabdian ini melibatkan 2 orang dosen yaitu dosen pendidikan matematika dan dosen pertanian serta 7 orang mahasiswa yang terdiri dari 2 mahasiswa pendidikan matematika dan 5 orang mahasiswa pertanian.

Sasaran dari kegiatan pengabdian ini yaitu:

1. Anak usia sekolah mulai dari kelas 1 SD sampai kelas X SMA sederajat yang kurang dalam pengetahuan matematika.

2. Bapak / Ibu kampung Tambat agar dapat menanam sayur dan bumbu dapur yang sekaligus dapat menjadi obat tradisional di halaman rumah mereka.

Bahan dan peralatan yang digunakan dalam pelaksanaan pengabdian ini yaitu:

1. Buku kegiatan pembelajaran matematika yang dibuat berbasis kearifan lokal dengan materi berhitung, kesebangunan dan kekongruenan, dan koordinat kartesius,

2. Powerpoint dan proyektor untuk menyampaikan materi kepada peserta pendampingan penanaman sayur dan bumbu dapur,

3. Modul tanaman sayuran dan bumbu dapur dibuat sesuai dengan jenis tanah dan kadar air serta ketersediaan air.

\section{HASIL DAN PEMBAHASAN}

Hasil

Pelaksanaan pengabdian ini dilakukan selama 3 bulan mulai tanggal 19 juni 2020 sampai 8 agustus 2020. Pelaksanaan ini terbagi atas sosialisasi menanam tanaman, pemberian tes awal dan tes akhir serta pelatihan dan pendampingan pembelajaran matematika dan menanam tanaman. Peserta pelatihan pembelajaran matematika tidak menentu, kadang lebih dari 15 dan kurang dari 15 anak yang terkadang berisikan anak-anak usia dini, sehingga tim mengambil keputusan untuk menjadikan 12 anak yang dijadikan sampel dalam penentuan target luaran pengabdian ini. Dan dalam pendampingan menanam di halaman rumah, peserta berjumlah 12 orang juga.

Pelaksanaan pengabdian dengan sasaran anak-anak usia sekolah di Kampung Tambat dilakukan dengan bantuan buku kegiatan pembelajaran matematika yang berisikan materi dan latihan soal berdasarkan kearifan lokal, sehingga anak-anak usia sekolah memahami dan menerapkannya apabila pelaksanaan kegiatan pengabdian ini telah usai. Penjelasan materi dan latihan dalam buku ini berhubungan dengan alam yang sering dilihat oleh anak-anak usia sekolah setempat. Anak-anak diajarkan konsep berhitung menggunakan kerang dan pinang yang sering ditemui. Selain itu, anakanak memahami konsep kesebangunan dan kekongruenan dengan mengamati ukuran buah kelapa, bagian dari bangunan yang ada di sekitar, serta belajar konsep sumbu koordinat kartesius dengan memanfaatkan bagian dari pohon kelapa. Sedangkan untuk pelaksanaan pengabdian dengan sasaran masyarakat kampung Tambat dibantu oleh modul tanaman sayuran dan bumbu dapur dibuat sesuai dengan jenis tanah dan kadar air serta ketersediaan air. Hal ini dilakukan agar masyarakat akan semakin rajin menanam tanaman sayuran dan bumbu dapur karena telah melihat hasil yang baik. Modul ini juga berisi tanaman yang selalu tumbuh setelah dipetik dan dipergunakan seperti bayam dan kangkung. Modul ini juga 
berisi tahapan penanaman dan kendala yang dapat dihadapi masyarakat dalam menanam.

Tahap evaluasi yang dilakukan pada pelatihan pengetahuan matematika yaitu dengan memberikan tes awal dan akhir agar dapat melihat tingkat kemampuan pemahaman berhitung, kesebangunan dan kekongruenan, serta koordinat kartesius. Hasil yang diperoleh yaitu anak-anak usia sekolah dapat mengerjakan soal dengan baik. Meskipun masih terdapat kendala dalam menyelesaikannya, namun dengan pemberian sedikit informasi dan mengingatkan materi yang telah diajarkan, anak menjadi dapat mengerjakan soal yang diberikan. Sedangkan tahap evaluasi yang dilakukan pada kegiatan pendampingan menanam tanaman sayur dan bumbu dapur yaitu dengan melihat masyarakat yang diberikan pupuk dan bibit tanaman sebanyak $75 \%$ telah menanam dan merawat tanamannya dengan baik

\section{Pembahasan}

Anak-anak usia sekolah dapat meningkatkan pengetahuan matematikanya dengan pelaksanaan pengabdian ini, hal ini disebabkan anak-anak dapat belajar dari apa yang ada disekeliling mereka seperti melihat perilaku anak lain atau orang dewasa (Mufidi, Salsabilla, Khairunnisa, Gunawan, \& Wibowo, 2019) dan tidak memerlukan biaya yang banyak dalam belajar. Karena belajar yang baik adalah belajar dari apa yang ada disekeliling kita dan kita mengetahui penerapan dari pelajaran tersebut. Sedangkan untuk masyarakat yang menanam tanaman sayur dampak ekonomi dan sosial dapat terlihat dari kemandirian hidup masyarakat dengan menanam sayur dan bumbu dapur yang dapat dijadikan obat di halaman mereka. Masyarakat yang menanam dapat mengurangi biaya belanja untuk memasak dan dapat pula menjual tanamannya agar mendapatkan penghasilan tambahan.

Pelaksanaan pengabdian pelatihan peningkatan pengetahuan matematika diawali dengan membagikan masker kepada anak-anak usia sekolah yang mengikuti kegiatan pengabdian ini. Hal ini dilakukan karena pada saat sosialisasi dan pertemuan yang dilakukan pertama kali, masyarakat dan anak-anak usia sekolah banyak yang tidak menggunakan masker, ketika ditanya mengapa tidak menggunakan masker, banyak yang menjawab tidak mempunyai masker. Oleh karena itu, tim pengabdi mempersiapkan masker untuk anakanak usia sekolah yang akan selalu berkomunikasi dengan jarak yang cukup dekat. Sebelum kegiatan pengabdian dilakukan, anakanak diminta untuk mencuci tangan tangan dan memberi jarak pada saat duduk menerima materi. Pembelajaran yang dilakukan pada saat pengabdian ini adalah pembelajaran yang dilakukan dalam ruangan dan di luar ruangan. Pembelajaran di dalam ruangan, yaitu tim memberikan materi dan soal yang berhubungan dengan sesuatu yang ada disekitar lingkungan anak-anak. Salah satu contohnya ditampilkan pada gambar 2 berikut.

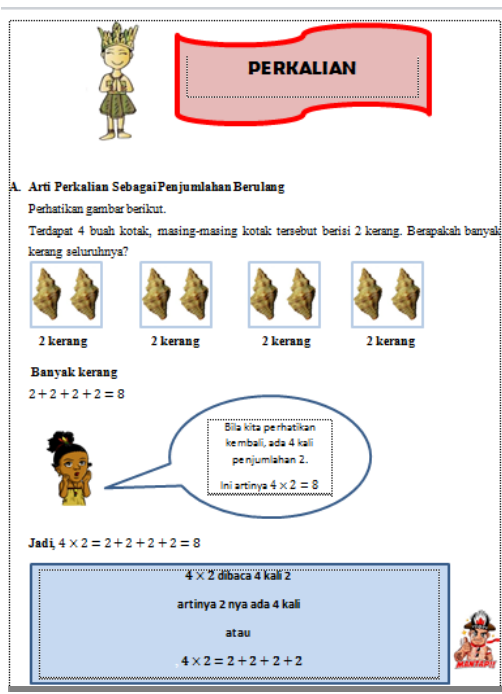

Gambar 2. Materi Operasi Bilangan Menggunakan Contoh Kerang 


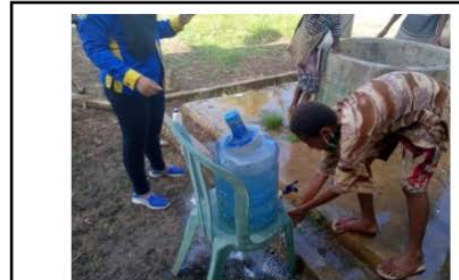

(a)

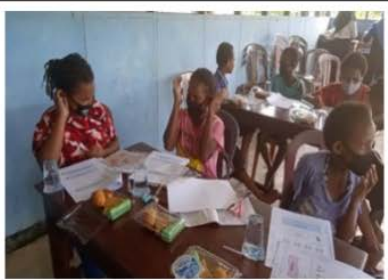

(b)

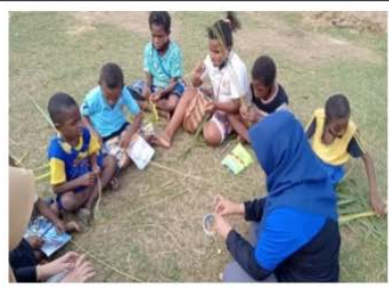

(c)

Gambar 3. Pelaksanaan Pengabdian Pelatihan Peningkatan Pengetahuan Matematika, (a) mencuci tangan sebelum melakukan kegiatan, (b) pembelajaran di dalam kelas, (c) pembelajaran di luar kelas.

Selain pembelajaran di dalam ruangan, anak-anak usia sekolah diajak untuk berkeliling untuk belajar mengenai bangun datar terlebih dahulu dan kemudian akan masuk ke materi kesebangunan dan kekongruenan. Gambar 3 (c) menunjukkan proses pembelajaran mengenal bangun datar dengan membuat sendiri bangun datar menggunakan lidi dan daun kelapa yang sebelumnya telah dikenalkan dengan mengelilingi kampung dan melihat bangun datar apa saja yang ada di sekitar. Kemudian anak-anak difasilitasi agar dapat memahami materi kesebangunan dan kekongruenan berdasarkan lingkungannya. Selanjutnya anakanak diajak untuk mengerjakan permasalahan yang ada pada buku kegiatan pembelajaran matematika yang telah dibagikan. Semua tahapan yang dilakukan pada materi kesebangunan dan kekongruenan dilakukan pula pada materi koordinat kartesius.

Pelaksanaan pengabdian kepada masyarakat ini bukan hanya berfokus pada pembelajaran bidang matematika saja namun pada bidang pertanian juga. Sasaran dari bidang pertanian ini adalah masyarakat kampung Tambat dengan jenis kelamin laki-laki dan perempuan, namun yang mengikuti kegiatan pengabdian ini mayoritas adalah perempuan karena laki-laki di kampung Tambat lebih senang berburu atau mencari ikan.
Pelaksanaan pengabdian di bidang pertanian ini dilakukan agar masyarakat memiliki kemampuan untuk menanam sayuran dan bumbu dapur untuk di komsumsi secara pribadi maupun nantinya dapat dijual kembali. Tanaman sayuran yang digunakan pada pengabdian ini adalah sayur bayam dan kangkung. Alasan pemilihan tanaman ini karena tanaman ini dapat terus tumbuh bila tidak dicabut sampai ke akar-akarnya bila ingin digunakan untuk memasak. Masyarakat disini diminta untuk membuat bedeng sesuai dengan bedeng percontohan yang dibuat setelah pemberian materi pada saat sosialisasi. Bedeng tanaman sayur dipisah dengan bumbu dapur. Tanaman bumbu dapur ditanam dengan mengunakan jarak tertentu.

Pada saat proses pertumbuhan berlangsung terdapat beberapa kendala seperti adanya hama belalang, kutu putih atau pun terjadi kekerdilan. Hal inilah yang dibutuhkan tim pengabdi, karena dengan adanya kendala atau permasalahan dalam menanam ini dan setelah diberitahukan cara mengendalikan permasalahan tersebut, masyarakat menjadi lebih mengetahui cara menanam dan mengendalikan permasalahan pada saat menanam.

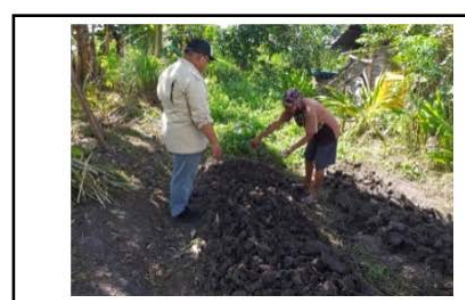

(a)

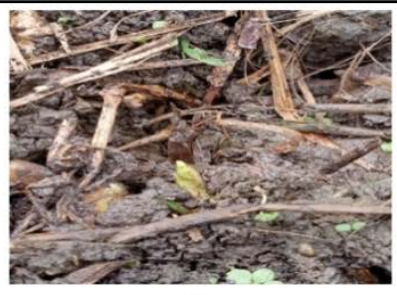

(b)

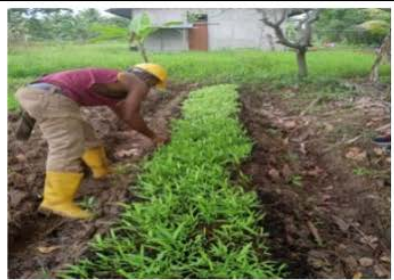

(c)

Gambar 4. Pelaksanaan Pengabdian Pendampingan Penanaman Bumbu Dapur dan Sayur, (a) mencuci tangan sebelum melakukan kegiatan, (b) pembelajaran di dalam kelas, (c) pembelajaran di luar kelas. 
Kontribusi yang diberikan aparat kampung dalam pelaksanaan pengabdian ini yaitu, mengumpulkan masyarakat dan anakanak usia sekolah, serta memberikan tempat yang nyaman serta fasilitas dalam pelaksanaan kegiatan pengabdian ini. Saat anak-anak diajak berkeliling dan mencari bahan untuk belajar materi kesebangunan dan kekongruenan, masyarakat ikut membantu dengan mengijinkan tim melihat lingkungan sekitar.

Salah satu faktor yang menghambat kegiatan pengabdian ini yaitu dengan adanya pandemik covid-19. Hal ini mengakibatkan pelaksanaan pengabdian menjadi dibatasi untuk jumlah pesertanya, baik untuk peserta pelatihan pengetahuan matematika maupun untuk peserta menanam tanaman sayur dan bumbu dapur. Serta saat belajar anak-anak diharuskan menggunakan masker, sedangkan anak-anak merasa kurang enak saat menggunakannya saat belajar. Ini menjadi suatu kebiasaan baru yang harus dipelajari anak-anak. Ada pula warga yang masih merasa takut untuk mengikuti kegiatan pengabdian ini dan melarang anaknya untuk mengikuti kegiatan ini, sehinga tim pengabdian memberikan pilihan bagi masyarakat yang ingin ikut saja yang dapat menjadi peserta pengabdian dan perlu memberikan pengertian kepada masyarakat bahwa pelaksanaan kegiatan ini tetap mengikuti protokol yang telah ditetapkan pemerintah. Pada saat pendampingan menanam tanaman sayur dan bumbu dapur, terkadang masyarakat tidak berada dirumah karena sedang berburu, sehingga tanaman yang ditanam tidak diperhatikan. Pada saat pelatihan pengetahuan matematika pun kadang anak-anaknya tidak datang karena sedang membantu orangtua mereka. Pada saat sosialisasi, anak-anak dan masyarakat tidak menggunakan masker dan meskipun jarak kursi telah diatur, masyarakat masih saja menggeser kursinya mendekati orang disebelahnya.

Solusi yang ditawarkan tim pengabdian kepada anak-anak dan masyarakat yaitu:

1. Memberikan pengertian kepada masyarakat bahwa peserta kegiatan dibatasi menjadi 15 orang saja di setiap bidang yaitu untuk pendidikan dan pertanian sehingga keterlaksana protokol yang diberkan pemerintah dapat terlaksana dengan baik.

2. Menyediakan sabun cuci tangan dan mengajak peserta melakukan cuci tangan sebelum kegiatan berlangsung

3. Membagikan masker dan menggunakannya sebelum kegiatan pengabdian berlangsung.

4. Mendatangi rumah-rumah warga untuk memanggil anak-anak usia sekolah yang menjadi peserta pengabdian

5. Meskipun anak-anak usia dini yang datang, kami tetap menerima dan memberikan pengetahuan matematika sesuai dengan umur mereka

6. Untuk tanaman yang di tanam dihalaman rumah, namun tidak ada pemilik rumahnya, kami melakukan perawatan yang seperlunya bila terjadi masalah ada tanaman tersebut

Rencana selanjutnya yang dirancang tim pengabdi bersama aparat dan masyarakat kampung Tambat yaitu:

a. Tetap melakukan pengontrolan dan pendampingan untuk tanaman yang telah ditanam

b. Masyarakat berencana membuat wadah belajar calistung di kampung Tambat dan warga pendidikan matematika menjadi tutor dalam pembelajaran calistung tersebut dalam bidang matematika saja.

\section{SIMPULAN}

Anak-anak yang mengikuti kegiatan pengabdian memiliki antusias yang tinggi, sehingga saat waktu pembelajaran habis, mereka masih tetap bersemangat mengerjakan latihan yang diberikan. Tidak hanya anak-anak usia sekolah saja, masyarakat yang menjadi peserta dalam pendampingan menanam tanaman sayur dan bumbu dapur pun sangat antusias dengan kegiatan tersebut. Masyarakat disini diminta untuk membuat bedeng sesuai dengan bedeng percontohan yang dibuat setelah pemberian materi pada saat sosialisasi. Hasil yang diperoleh dalam kegiatan ini yaitu anak usia sekolah telah dapat memahami dan 
menyelesaikan permasalahan dalam operasi bilangan, kesebangunan dan kekongruenan serta sistem koordinat. Masyarakat kampung tambat pun dapat menanam dan merawat tanamannya dengan baik serta mempergunakannya dalam kehidupan sehaihari.

\section{UCAPAN TERIMAKASIH}

Penulis mengucapkan terima kasih kepada Rektor Universitas Musamus, Dekan Fakultas Keguruan dan Ilmu Pendidikan Universitas Musamus, Ketua Jurusan Pendidikan Matematika Universitas Musamus, Aparat Kampung Tambat Distrik Tanah Miring Kabupaten Merauke, Masyarakat Kampung Tambat Distrik Tanah Miring Kabupaten Merauke, mahasiswa jurusan pendidikan matematika dan mahasiswa jurusan agroteknologi, yang telah membantu suksesnya keterlaksanaan kegiatan pengabdian ini. Ucapan terima kasih terkhusus diberikan kepada Kementrian Pendidikan dan Kebudayaan yang telah mendanai kegiatan pengabdian ini.

\section{DAFTAR PUSTAKA}

Arman, S., Asuni, S. A. B., \& Inekso, D. A. N. R. (2013). Implikasi Kearifan Lokal Bagi Pengelolaan Taman Nasional Wasur. Media Konservasi, 3, 18.

Asriyani, N., \& Hastuti. (2019). Local Wisdom and Public Participation in Landslide Disasters in Girimulyo Kulon Progo. IOP Conference Series: Earth and Environmental Science, 271.

Basuki, F. R., Jufrida, \& Suryanti, K. (2019). Identification of Potential Local Wisdom of Senamat Ulu Village (Electrical Independent Village) as a Source of Science Learning. Journal of Physics: Conference Series, 1, 1185.

BPS. (2018). Distrik Tanah Miring Dalam Angka Tahun 2018.

Kurtanto, E. (2013). Pembelajaran Calistung.

Kusuma, R. S. (2018). Peran Sentral Kearifan Lokal Dalam Peningkatan Kualitas Pendidikan. Jurnal Pendagogik, 5(2), 228-239.

Mufidi, A. F., Salsabilla, T., Khairunnisa, M.
F., Gunawan, G. H., \& Wibowo, H. (2019). Edukasi Anak Binaan Sanggar Waringin tentang Bullying Melalui Penyuluhan Dengan Metode Sosiodrama. Jurnal Kumawula: Jurnal Pengabdian Kepada Masyarakat, 2(2), 175-182. https://doi.org/http://10.24198/kumawula. vli3.24565

Narulita, A., Fajar, C. M., Riesma, R. S. N., Rachman, J. B., Aditiany, S., \& Dipura, D. S. (2019). Sosialisasi Citra Baru Pencak Silat sebagai Soft Power Indonesia Kepada Siswa SMP Negeri 2 Kota Bandung. Jurnal Kumawula: Jurnal Pengabdian Kepada Masyarakat, 2(1), 72-92. https://doi.org/http://10.24198/kumawula. vli3.23461

Toharudin, U., \& Kurniawan, I. S. (2019). Learning Models Based Sundanese Local Wisdom: Is It Effective to Improve Student's Learning Outcomes? Journal of Physics: Conf. Series 1157, 022069, 1-6.

Ufie, A. (2016). Mengonstruksi Nilai-Nilai Kearifan Lokal (Local Wisdom) Dalam Pembelajaran Muatan Lokal Sebagai Upaya Memperkokoh Kohesi Sosial (Studi Deskriptif Budaya Niolilieta Masyarakat Adat Pulau Wetang Kabupaten Maluku Barat Daya, Propinsi Maluku). Jurnal Pendidikan Dan Pembelajaran (JPP), 3(2), 79-89. Wagiran. (2011). Kedua), Pengembangan Model Pendidikan Kearifan Lokal Dalam Mendukung Visi Pembangunan Provinsi Daerah Istimewa Yogyakarta 2020 (Tahun. Jurnal Penelitian Dan Pengembangan, 3(3), 85-100. 